\title{
Comparative Analysis of Strategies Applied in Persian and English Translations of Quranic-Arabic Culture Bound Term "Jilbab" (33:59)
}

\author{
Fatemeh Zahra Nazari Robati (Corresponding author) \\ School of Literature and Humanities, Narjes University \\ PO box 7719755851, Rafsanjan cultural center (museum), Modares Sq., Modares Blvd., Rafsanjan, Kerman, Iran \\ E-mail: nazari.sodo@gmail.com
}

Received: 07-09-2015

Accepted: 06-12-2015

Published: 01-03-2016
Advance Access Published: December 2015

URL: http://dx.doi.org/10.7575/aiac.ijalel.v.5n.2p.64

The research is financed by Narjes Uuniversity (Kerman, Iran).

\begin{abstract}
Today TS focus has altered from linguistics to cultural studies. Culture is the way of life; as such every text is culturebound and includes items that are culture-specific. Translating these cultural-specific items (henceforth CSI) has made translation a complicated task. Hijab, one of the controversial issues of the present day of Islam in the world is defined in one way through presenting terms for women clothing such as "Jilbab" in Quran. Using Davies' (2003) strategies of translating CSIs, as the theoretical framework, taking the Quranic-Arabic culture bound term "Jilbab" (33:59) as the object of the study, this corpus-based comparative descriptive research was an attempt to compare totally 64 Persian and English (54 in Persian and 12 in English) translations of this term with two concerns regarding the adopted translation strategies: a) linguistic (Persian and English) concern, and b) translators' gender concern (male and female). The analysis of data showed that the most adopted strategy in both Persian and English corpus was localization (in Persian 35.71\%, and in English 46.66\%). Male translators in Persian had more tendency to use localization (36.53\%) and female translators to addition and globalization (each 50\%). Male translators in English were more inclined to localization (45.83\%), and the female have used preservation, addition, globalization and localization with the same frequency $(25 \%)$. Totally male translators were inclined to localization $(39.47 \%)$, while the female to globalization and addition $(33.33 \%)$.
\end{abstract}

Keywords: CSI, Translation strategies, Comparative analysis, Quran, "Jilbab"

\section{Introduction}

Recently "linguistics theories of translation have been sidelined and attention has centered on translation as cultural transfer and the interface of translation as cultural transfer and the interface of translation with other growing disciplines within cultural studies" (Munday, 2006, p. 141). Nida, examining the problematic issue of non-equivalence in translation asserts that "differences between cultures may cause more severe complications for the translator than do differences in language structures" (1964, p. 30). Actually, the hardest thing in translation is finding right equivalent for culture-specific items. Dealing with culture-specific items is a complex technical issue raised in cultural translation (Sturge, 2009, p. 67). The Holy Quran as any other religious text due to its guiding role includes doctrines concerning different areas of human life. One of these doctrines is related to issue of Hejab, and specifically women proper clothing in society. Quran is in Arabic; thus its words and expressions are Arab-culture bound. Concerning the sensitive issue of Hejab, having in mind Arabic-culture bound nature of Quran representation of female clothes, providing the proper equivalents for these words through translation stands as an important issue. Two words relating women clothes have been presented in Quran: "Khamar" and "Jilbab". Different scholars have presented different strategies for translating CSIs. The present study examines the strategies adopted by Persian and English (male and female) translators in translating the term "Jilbab".

\section{Literature Review}

In this part some definitions of the term culture and culture-specific items, categorization of CSIs and strategies for translating them are presented.

2.1 Culture-Specific Items: Definition and Types

To Newmark, culture is "the way of life and its manifestation that are peculiar to a community that uses a particular language as its means of expression." (1988, p. 94). Vermeer believes that "culture consists of everything one needs to know, master and feel, in order to assess where members of a society are behaving acceptably in their various roles" (as cited in Katan, 2009, p. 82). Actually, despite various definitions of the complex word culture, all of them include notions such as customs, habits, beliefs, geographical realia, national literature, folklore, religious aspects, etc. 
Ambiguous nature of CSIs is evident in various terms and classifications presented for them. In translation studies the following terms are used: “ 'cultural' words” (Newmark, 1988, p. 95), “ 'culture-specific' concepts” (Baker, 1992, p. 21), "realia" or culture-bound phenomena (Robinson, 1997, p. 171), culture-bound elements (Hagfors, 2003) and cultural concepts or culture-specific items (Davies, 2003).

Different classifications have been presented for CSIs by different translation scholars. These classifications are presented in Table 1.

Table 1. Classification of CSIs by different scholars

\section{Scholar}

Baker (1992, p. 21)

Newmark (1988, pp. 94-103)

\section{Classification of CSIs}

1. Abstract or concrete

2. Religious belief

3.Social custom

4. Type of food

1. Ecology (flora, fauna, winds,etc)

2. Material culture (artifacts, food, clothes, houses and towns, transport)

3. Social culture (work and leisure)

4. Organizations, customs, ideas (political, social, legal, religious or artistic)

5. Gestures and habits

Kujamäki (1998, pp. 26-27, as cited in Leppihalme, 2010, p. 127)

Thriveni (2001)

Pavlović and Poslek (2003, pp. 160-163)

Antonin (2004, p. 154 )

Espindola and Vascancellos (2006, pp. 49-50)

\section{Society}

2. Leisure activities

3. Proper names

4. Nature

5. Mythology

6. Everyday items (clothes, food, tools, etc.).

1. Proper names

2. Grammatical forms which show respect and euphemism

3. Social relationships

4. Life-styles and values

5. Dress code or ornaments and symbols behind them

6. Food habits

7. Customs and traditions

9. Religious elements, myths and legends

1. Ecology

2. Everyday life

3. Material culture

4. History

5. Religion

6. Economy

7. Political and administrative functions and institutions

8.The armed forces

9. Education

10. Forms of address

11. Gestures and habits

12. Work

13. Leisure and entertainment

1. Education

2. Politics

3. History

4. Art

5. Institutions

6. Legal systems

7. Units of measurement

8. Place names

9. Foods and drinks

10. Sports

11. National pastimes

1.Toponyms

2. Anthroponyms

3. Forms of entertainment

4. Means of transportation

5. Fictional character
8. Beliefs and feelings

10. Geographical and environmental phenomena 
6. Legal system

7. Local institution

8. Measuring system

9. Food and drink

10. Scholastic reference

11. Religious celebration

12. Dialect

Katan (2009, pp. 89-90)

1. Environment

2. Behavior

3. Strategies

4. Values and beliefs

5. Identity

6. Role, mission in society

\subsection{CSIs: Translation Strategies}

Aixelá (as cited in Alvarez \& Vidal, 1996) writes that:

In translation, a CSI does not exist of itself, but as the result of a conflict arising from any linguistically represented reference in a source text which, when transferred to a target language, poses a translation problem due to the nonexistence or to the different value of the given item in the target language culture... CSIs are those textually actualized items whose function and connotations in a source text involve a translation problem in their transference to a target text, whenever this problem is a product of the nonexistence of the referred item or of its different intertextual status in the cultural system of the readers of the target text. (pp. 57-58).

This shows that due to vitality and complexity of translating CSIs, the translator must be aware of cultural differences between ST and TT.

For translating CSIs, the translator resort to translation strategies. Translation scholars have presented various strategies for translating the SCIs. Taxonomies of these strategies are presented in Table 2.

Table 2. Taxonomies of strategies for translating CSIs

\section{Scholar}

Newmark (1988, pp. 81-93)
1.Transference

2. Naturalization

3. Cultural equivalent

4. Functional equivalent

5. Descriptive equivalent

6. Synonym

7. Through translation

8. Modulation

9. Recognized translation

10. Compensation

11.Componential analysis

12. Paraphrase

13. Couplets

14. Notes, addition, glosses

Baker (1992, pp. 26-42)

1.Translation by a more general word (superordinate)

2. Translation by a more neutral/less expressive word

3. Translation by cultural substitution

4. Translation using a loan word or loan word plus explanation

5. Translation by paraphrase using a related word

6. Translation by paraphrase using unrelated words

7. Translation by omission

8. Translation by illustration

Hervey and Heggins (1992, p. 28)
1. Exoticism

2. Cultural borrowing

3. Calque

4. Communicative translation

5. Cultural transplantation

Venuti (1992, p. 20$)$

Aixela (1996, pp. 61-64)
1. Foreignization

2. Domestication

A. Conversion

1. Repetition

2.Orthographic

3. Adaptation 
4. Linguistic (non-cultural) translation

5. External gloss

6. Internal gloss

B. Substitution

1. Synonymy

2. Limited universalization

3. Absolute universalization

4. Naturalization

5. Deletion

6. Autonomous creation

C. Potential strategies

1. Compensation

2. Dislocation

3. Attenuation

Mailhac (1996, pp. 140-141)

1. Cultural borrowing

2. Literal translation/calque

3. Definition

4. Cultural substitution

5. Lexical creation

6. Deliberate omission

7. Compensation

8. Combination of procedures

9. Footnote

Ivir (2002/2003, p. 117)

1. Borrowing

2. Definition and paraphrase

3. Literal translation

4. Substitution

5. Lexical creation

6. Addition

7. Omission

Davies (2003, pp. 72-88)

1. Preservation

2. Addition

3.Omission

4. Globalization

5. Localization

6. Transformation

7. Creation

\section{Term "Jilbab" as a CSI}

Based on Newmark's categorization, "Jilbab" the subject of the present study is an example of material culture. The word "Jilbab" (33:59), defined as a wide dress worn by women on other clothes is one of two words used in Quran referring to female clothing:

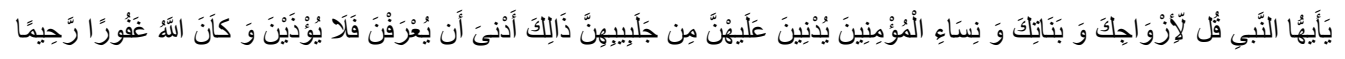

(Yāāayyuhannabiyyuqulli-az-wājikawabanātikawanisāā-il-mu-minīnayud-nīna'alay-h inna minjalābībihinDhālikaad-nāāayyu'-raf-nafalāyu-dhay-naWakānallāhughafūrarraḥīmā)

Pickthall: "O Prophet! Tell thy wives and thy daughters and the women of the believers to draw their cloaks close round them) when they go abroad (That will be better, so that they may be recognized and not annoyed. Allah is ever Forgiving, Merciful."

As to this verse, God asks prophet to tell three groups of women: 1) his wives, 2) his daughters and 3) women of believers to behave as the verse says: "to draw close around them their 'Jilbab" ".

Here are two conclusive definitions provided by interpretations (Tafsir) for the term "Jilbab":

a) Najafi Khomeini (as cited in Jami al-Tafasir Noor 2) provides three equivalents for term "Jilbab": chador, scarf and long dress. According to him, as this term was used for referring to three kinds of clothes, we can't use it for referring to only one clothes.

b) Hossein Sha Abdol-azimi (as cited in Jami al-Tafasir Noor 2) defines "Jilbab" as a kind of cloth worn on Khamar (whatever worn on head), which covers head and body from top to down.

Concerning the culture bound nature of the term, its various equivalents in commentaries, and the opacity of its real reference in different ages, having in mind the appearance of different clothes during the years after revelation of Quran, different equivalents have been chosen by different translators in Persian and English as shown in Table 3. Thus, the importance of examining translations of the term. (The period of translations are based on the Islamic calendar). 


\begin{tabular}{|c|c|c|c|c|c|c|c|}
\hline Period & $4^{\text {th }}$ & $6^{\text {th }}$ & $10^{\text {th }}$ & $12^{\text {th }}$ & $13^{\text {th }}$ & $14^{\text {th }}$ & $15^{\text {th }}$ \\
\hline \multirow{9}{*}{$\begin{array}{c}\text { Persian } \\
\text { Equivalents }\end{array}$} & \multirow[t]{9}{*}{ جادر } & جادر & \multirow[t]{9}{*}{ جادر } & \multirow[t]{9}{*}{ جادر } & \multirow[t]{9}{*}{-} & جادر & جادر \\
\hline & & ردا & & & & مقنعه & بوشش/بوشش بلند \\
\hline & & طبلسنان & & & & رويُش & روسرى بزرگ/بلند \\
\hline & & \multirow[t]{6}{*}{ يبير اهن } & & & & روسرى بزرگگ/بلند & رويوش \\
\hline & & & & & & خمار & حجاب \\
\hline & & & & & & جلباب & مقنعه بزرى \\
\hline & & & & & & & لباس وسيع \\
\hline & & & & & & & سرانداز \\
\hline & & & & & & & جلباب \\
\hline \multirow{8}{*}{$\begin{array}{l}\text { English } \\
\text { Equivalents }\end{array}$} & \multirow[t]{8}{*}{-} & \multirow[t]{8}{*}{-} & \multirow[t]{8}{*}{-} & \multirow[t]{8}{*}{-} & \multirow[t]{8}{*}{ cloak } & cloak & cloak \\
\hline & & & & & & outer garment & outer/over/loose garment \\
\hline & & & & & & veils & Jilbab \\
\hline & & & & & & & scarf \\
\hline & & & & & & & chador \\
\hline & & & & & & & Shirts \\
\hline & & & & & & & gowns \\
\hline & & & & & & & wide dresses \\
\hline
\end{tabular}

\section{Research Questions}

As the word "Jilbab" has been presented as a symbol for chaste women clothes of all ages, considering the importance and sensitivity of translating Quran and more importantly translating the CSIs, the researcher studied the translations of the word "Jilbab" in order to answer the following questions:

1. Which translation strategies have been adopted in Persian and English translations of the term "Jilbab"?

2. Which translation strategies have been adopted by male and female translators in both Persian and English corpus?

\section{Methodology}

For the purpose of gathering the required data of this corpus-based descriptive study totally 64 Persian and English translations of verse 59 of surah Al-Ahzab taken from Jami al-Tafasir Noor 2 software in addition to two other female translations, by Sahee International (1997) and Laleh Bakhtiar (2007), were arranged chronologically in tables including columns determining the translator, the text of translation, period of translation, and gender of the translator. Among these translations 53 were by male translators, 6 were by female translators, the gender of four was unknown, and one was done by both genders together (by Muhammad Ahmad and Samira Ahmad), 12 in English and the rest 52 in Persian. The data of the study were examined for the comparison of strategies applied in translation of the CSI, "Jilbab". The strategies were identified and compared; the results of which are provided and discussed under results and discussion section.

\section{Theoretical Framework}

This study enjoys the theoretical framework of Davies. Regarding the translation of CSIs Davies provides seven translation strategies: preservation, addition, omission, globalization, localization, transformation and creation.

\subsection{Preservation}

Preservation is the first translation strategy provided by Davies. As she says, when a translator encounters an entity which has no close equivalent in the target language, s/he decides to "to maintain the source text term in the translation" (Davies, 2003, p. 73). This procedure has been referred to by other scholars using different terms, so that Baker (1992) calls it translation using a loan word, Aixelá (1996) repetition, and Newmark (1988) transference. According to these scholars, through this procedure, elements of the source language enter another language in its original form and may become completely an element of that language. The extent of toleration of different speech and language communities to this procedure depends on the type of audience.

\subsection{Addition}

The second strategy proposed by Davis is addition. As Davis (2003) says, when keeping the source language CSI causes "obscurity", the translator decides to preserve "the original item but supplement" it with necessary information (p. 77). The supplementary information is of two types: extratextual and intratextual; called "extratextual gloss" and "intratextual gloss" by Aixela. According to Davis (2003) the decision of the type of supplementary information being provided in the text depends on the translators' knowledge of the background of the target audience.

When providing "explanations of the meaning or implications of the CSI" seems necessary to the translator, s/he may provide these additional information as extratextual gloss in the form of endnote, footnote, glossary, commentary/ translation in brackets or italics, etc (Aixela, 1996, p. 62). Newmark calls this strategy note, and defines it as any additional information in the translation procedures (Newmark, 1988). Footnotes provide additional information and draw attention to the differences of the SL and TL in the case of nonequivalent meaning (Nida, 1964). The direct insertion of additional information in the text brings about the second type of addition, namely intratextual addition. As 
Aixela (1996) explains, this is used when the translator deems the provision of the "gloss as an indistinct part of the text, usually so as not to disturb the reader's attention" (p. 62).

\subsection{Omission}

The third strategy is omission. Omission is the opposite phenomenon to addition. According to Davies the motives for this decision are as follows: When the translator finds no adequate way for transferring the original meaning or when the amount of effort needed for providing the meaning through paraphrase or equivalent is not acceptable on behalf of either the translator or translation's readers (Davies, 2003, p. 80).

Traditionally identifying omission with translators' failure to render the necessary translation unit has caused it not be a common strategy (Dimiriu, 2004). The purposes of using omission according to Dimitriu (2004) are : a) ensuring linguistic accuracy and stylistic acceptability leveling differences in grammatical structures of languages and avoiding text redundancy; b) presenting the information in a more concise manner; c) presenting only essential information; d) avoiding unnecessary culture, time and space bumps; e) observing text-type and genre-related norms; f) observing editorial norms, for the purpose of avoiding cultural taboos; g) supporting the ideology of a political system; and, h) translating for a particular group taking into account its characteristics of age, education, gender and social class.

\subsection{Globalization}

The fourth strategy is globalization. Davies (2003) describes it as "the process of replacing culture-specific references with ones that are more neutral or general" (p. 83), this way the audiences of the text would be in a wider range of cultural background. Newmark uses the term functional equivalent for this strategy because of using a cultural neutral word. (Newmark, 1988, p. 83). Aixela's preferred term is universalization, which is divided into two types: limited universalization and absolute universalization (Aixela, 1996, p. 63).

\subsection{Localization}

The fifth strategy which is opposed to globalization is called localization. For the purpose of avoiding "loss of effect" and "instead of aiming for 'culture-free' descriptions", the translators use a reference used in the target audience's culture (Davies, 2003, p. 84). Naturalization is Aixela's preferred term for this strategy. According to her in this way CSI is brought "into the intertextual corpus felt as specific by the target language culture" (Aixela, 1996, p. 63). Newmark (1988, p. 82) defines this strategy under three headings: transference, naturalization and cultural equivalent. Calling it cultural substitution, Baker (1992) claims that in this strategy the culture-specific item does not have the same prepositional meaning but is understandable for the target reader.

\subsection{Transformation}

Davies's (2003) sixth strategy is transformation, mentioning the obscurity of distinction between this strategy and other ones she asserts that it occurs "where the modification of a CSI seem to go beyond globalization or localization, and could be seen as an alteration or distortion of the original" (p. 86).

\subsection{Creation}

The last strategy introduced by Davies is creation "where translators have actually created CSIs not present in the original text" (Davies, 2003, p. 88). Aixelá, believing in the rare usage of this strategy, calls it "autonomous recreation" (1996, p. 64).

\section{Results and Discussion}

The analysis of the corpus of the present study was done based on two concerns regarding the adopted strategies: a) linguistic (Persian and English) concern, b) translators' gender (male and female) concern.

The analysis of data shows that in both Persian and English corpus none of the two last strategies: transformation and creation have been applied. And in Persian omission is not used at all.

7.1 Linguistic Concern

The results of analyzing the total corpus, considering the linguistic concern, are provided in Table 4.

Table 4. Frequency and percentage of adopted strategies in Persian and English corpus

\begin{tabular}{lcccccccccc}
\hline Strategy & \multicolumn{2}{c}{ Preservation } & Addition & \multicolumn{3}{c}{ Omission } & \multicolumn{2}{c}{ Globalization } & \multicolumn{2}{c}{ Localization } \\
\hline Measure & Fr. & $\%$ & Fr. & $\%$ & Fr. & $\%$ & Fr. & $\%$ & Fr. & $\%$ \\
\hline Persian & 5 & 8.92 & 14 & 25 & 0 & 0 & 17 & 30.35 & 20 & 35.71 \\
\hline English & 2 & 6.66 & 7 & 23.33 & 1 & 3.33 & 6 & 20 & 14 & 46.66 \\
\hline Total & 7 & 8.13 & 21 & 24.41 & 1 & 1.16 & 23 & 26.74 & 34 & 39.53 \\
\hline
\end{tabular}

Note. Fr. = frequency.

Regarding the total corpus, as shown in Table 4, the applied strategies in order of appearance is: localization (39.53\%), globalization $(26.74 \%)$, addition $(24.41 \%)$, preservation $(8.13 \%)$ and omission $(1.16 \%)$. The order of appearance of strategies in the Persian corpus is: localization (35.71\%), globalization (30.35\%), addition (\%25) and then preservation (8.92\%); the order in English corpus is: localization (46.66\%), addition (23.33\%), globalization (20\%), preservation $(6.66 \%)$, and omission (3.33\%). The strategy of addition is either intratexual or extratextual. These data are depicted in Figure 1. 


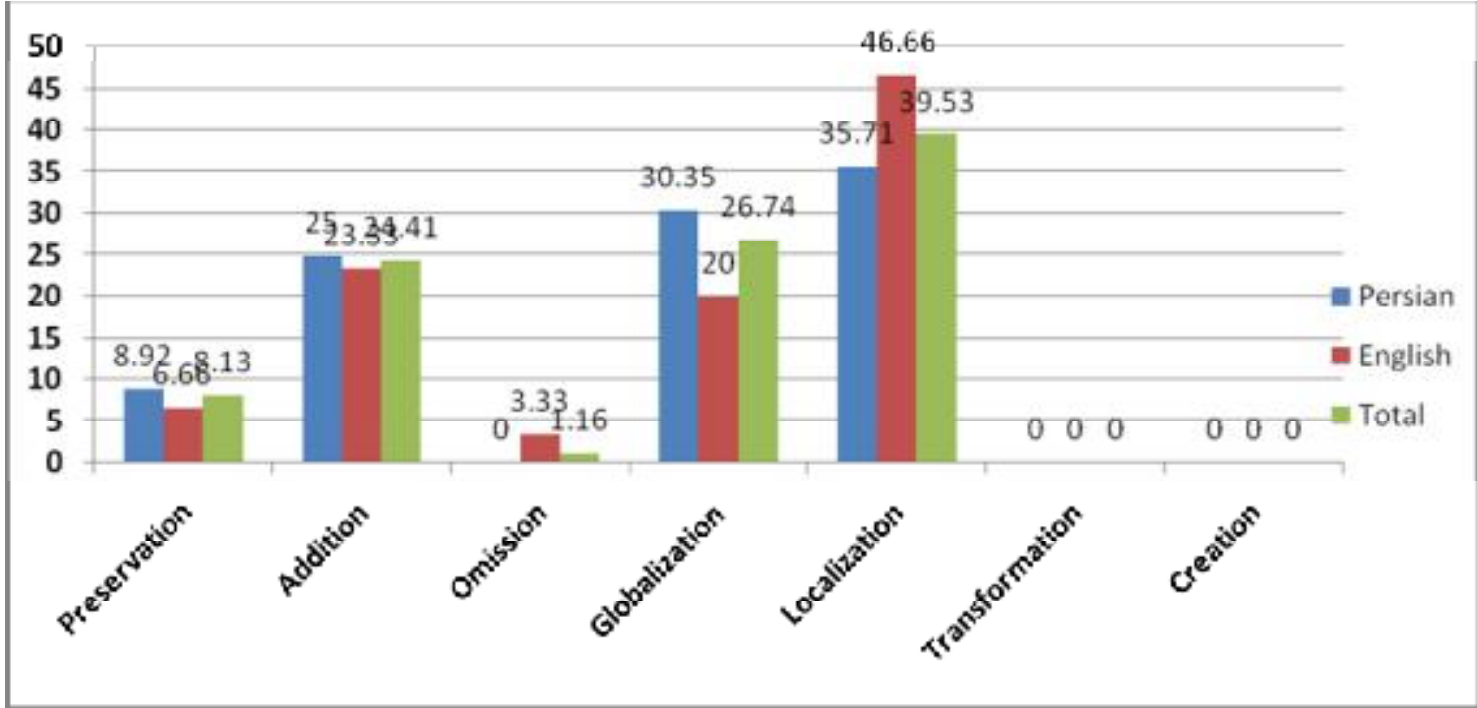

Figure 1. Adopted Strategies in Persian and English Corpus

In both Persian and English corpus, the adopted strategy mostly revolves around the three strategies of localization, globalization, and addition. In each case the adopted strategy can be ideologically interpreted (which can be the concern of another research).

\subsubsection{Examples of Adopted Strategies}

Some examples of the application of strategies in Persian and English corpus by either male or female translators are presented in the following tables.

Table 5. Examples of application of preservation strategy

\begin{tabular}{|c|c|}
\hline ST:(33:59) & 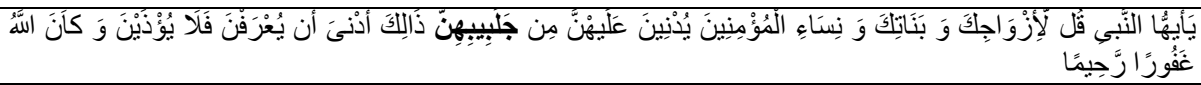 \\
\hline \multicolumn{2}{|r|}{ Preservation } \\
\hline $\begin{array}{l}\text { Persian example: } \\
\text { Muhammad Javad } \\
\text { Najafi Khomeini (male) }\end{array}$ & 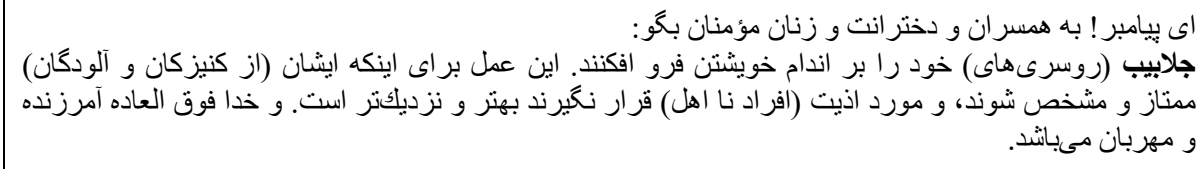 \\
\hline \multicolumn{2}{|c|}{$\begin{array}{l}\text { The word "جلابيب" has been repeated in the Persian translation. In this example the strategy of extratextual addition } \\
\text { through using parenthesis for providing more information (روسرىهاى) has been adopted as well. }\end{array}$} \\
\hline $\begin{array}{l}\text { English Example: } \\
\text { Tahereh Safarzadeh } \\
\text { (female) }\end{array}$ & $\begin{array}{l}\text { O, Messenger! Advise your wives, your Daughters and the believing women To let down } \\
\text { their jilabib, «1» this will cause Them to be distinguished from those Women who do } \\
\text { not cover their heads And thus will bar the vulgar men from Making trouble for them. } \\
\text { And Allah is The Merciful Forgiving] He will out of His Mercy bestow Forgiveness on } \\
\text { those Who did not respect the matter before This. } \\
\text { 1. Jilabib plural of Jilbab meaning: A scarf covering the head, the neck and the } \\
\text { bosom; also a loose garment which covers the whole body. } \\
\text { 2. Sunnat Allah signifies: Allah's Line of Conduct or } \\
\text { Allah's Way }\end{array}$ \\
\hline
\end{tabular}

Table 6. Examples of addition strategy

\begin{tabular}{|c|c|}
\hline & Addition \\
\hline $\begin{array}{l}\text { Persian example: Naser } \\
\text { Makarem Shirazi (male) }\end{array}$ & 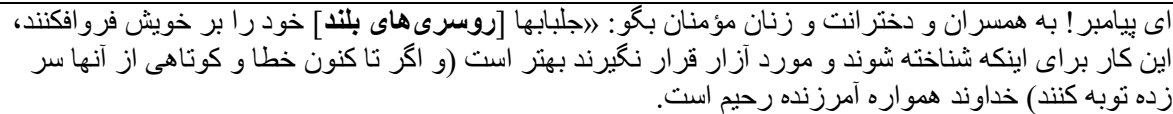 \\
\hline \multicolumn{2}{|c|}{ 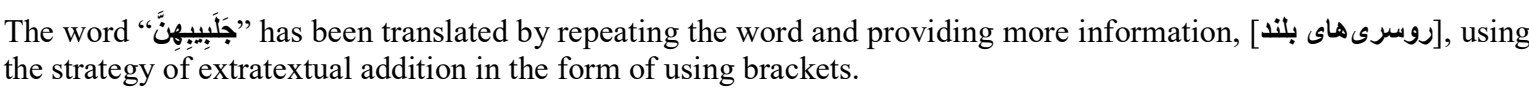 } \\
\hline
\end{tabular}


English Example:

Umm Muhammad

(known under the pseudonym of Saheeh International) (female)

O Prophet, tell your wives and your daughters and the women of the believers to bring down over themselves [part] of their outer garments.1130 That is more suitable that they will be known1131 and not be abused. And ever is Allāh Forgiving and Merciful. 1132

1130 The jilbāab, which is defined as a cloak covering the head and reaching to the ground, thereby covering the woman's entire body.

1131 As chaste believing women.

1132 Or "and Allāh was Forgiving and Merciful" of what occurred before this injunction or before knowledge of it.

Here the equivalent "outer garment" has been explained more by providing a footnote, explaining the meaning of the word "Jilbab", thus applying extratextual addition.

The only example of application of omission in the corpus is provided in Table7. This strategy has been applied in translation to avoid unnecessary culture, time and space bumps.

Table 7. Example of omission strategy

\begin{tabular}{|c|c|}
\hline \multicolumn{2}{|r|}{ Omission } \\
\hline $\begin{array}{l}\text { English Example: } \\
\text { Mohamad Sarvar(male) }\end{array}$ & $\begin{array}{l}\text { Prophet, tell your wives, daughters, and the wives of the believers to cover their bosoms } \\
\text { and breasts. This will make them distinguishable from others and protect them from } \\
\text { being annoyed. God is All-forgiving and All-merciful. }\end{array}$ \\
\hline & term "جَلبياينهن" as an unnecessary cultural bump, no clothes name has been used. Only the \\
\hline
\end{tabular}

Table 8. Examples of globalization strategy

\begin{tabular}{|c|c|}
\hline \multicolumn{2}{|r|}{ Globalization } \\
\hline $\begin{array}{l}\text { Persian example: } \\
\text { Mohammad Kazem } \\
\text { Moezi (male) }\end{array}$ & 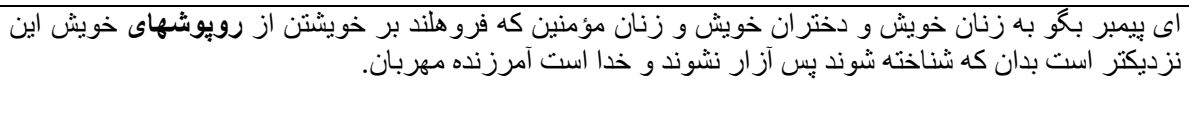 \\
\hline \multicolumn{2}{|c|}{$\begin{array}{l}\text { The word "رويوش" as an equivalent for "Jilbab", is the application of a general word including whatever clothes } \\
\text { worn on other clothes. }\end{array}$} \\
\hline $\begin{array}{l}\text { English Example: } \\
\text { Mohamad Ahmad and } \\
\text { Samira Ahmad } \\
\text { (male and female) }\end{array}$ & $\begin{array}{l}\text { You, you the prophet, say to your wives and your daughters and the believers' women } \\
\text { they) F (near) lengthen (on them from their shirts/ gowns/ wide dresses, that) is (nearer } \\
\text { that) E (they) F (be known) better than being identified (, so they) F (do not be harmed } \\
\text { mildly/ harmed, and God was/ is forgiving, merciful. }\end{array}$ \\
\hline \multicolumn{2}{|c|}{$\begin{array}{l}\text { Words "shirts/ gowns/ wide dresses" are general words, not specific to any culture, thus making the translation } \\
\text { accessible to a wider range of cultural backgrounds. }\end{array}$} \\
\hline
\end{tabular}

Table 9. Examples of localization strategy

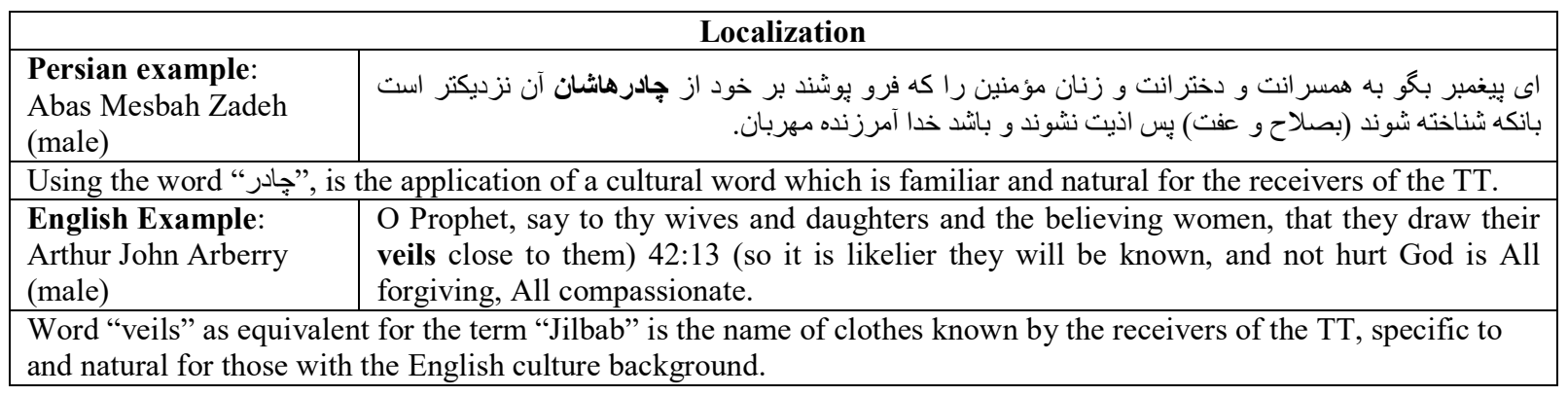

\subsection{Translator's Gender Concern}

In Table 10 and 11 the data related to application of strategies in Persian and English corpus by male and female translators are provided.

Table 10. Frequency and percentage of adopted strategies in Persian corpus concerning the gender of the translator

\begin{tabular}{lcccccccccc}
\hline Strategy & \multicolumn{2}{c}{ Preservation } & \multicolumn{2}{c}{ Addition } & \multicolumn{2}{c}{ Omission } & \multicolumn{2}{c}{ Globalization } & \multicolumn{3}{c}{ Localization } \\
\hline Measure & Fr. & $\%$ & Fr. & $\%$ & Fr. & $\%$ & Fr. & $\%$ & Fr. & $\%$ \\
\hline Male & 5 & 9.61 & 13 & 25 & 0 & 0 & 15 & 28.84 & 19 & 36.53 \\
\hline Female & 0 & 0 & 1 & 50 & 0 & 0 & 1 & 50 & 0 & 0 \\
\hline Total & 5 & 8.92 & 14 & 25 & 0 & 0 & 17 & 30.35 & 20 & 35.71 \\
& & & & & & & $\begin{array}{c}1 \text { is } \\
\text { combined }\end{array}$ & \multicolumn{2}{c}{$\begin{array}{c}1 \text { is } \\
\text { unknown }\end{array}$} \\
\hline
\end{tabular}


As the data of Table 10 shows the order of application of strategies by male translators in Persian corpus is: localization (36.53\%), globalization (28.84\%), addition (25\%) and preservation $(9.61 \%)$. Female translators have only used addition and globalization with the same frequency (50\%). These data are depicted in Figure 2.

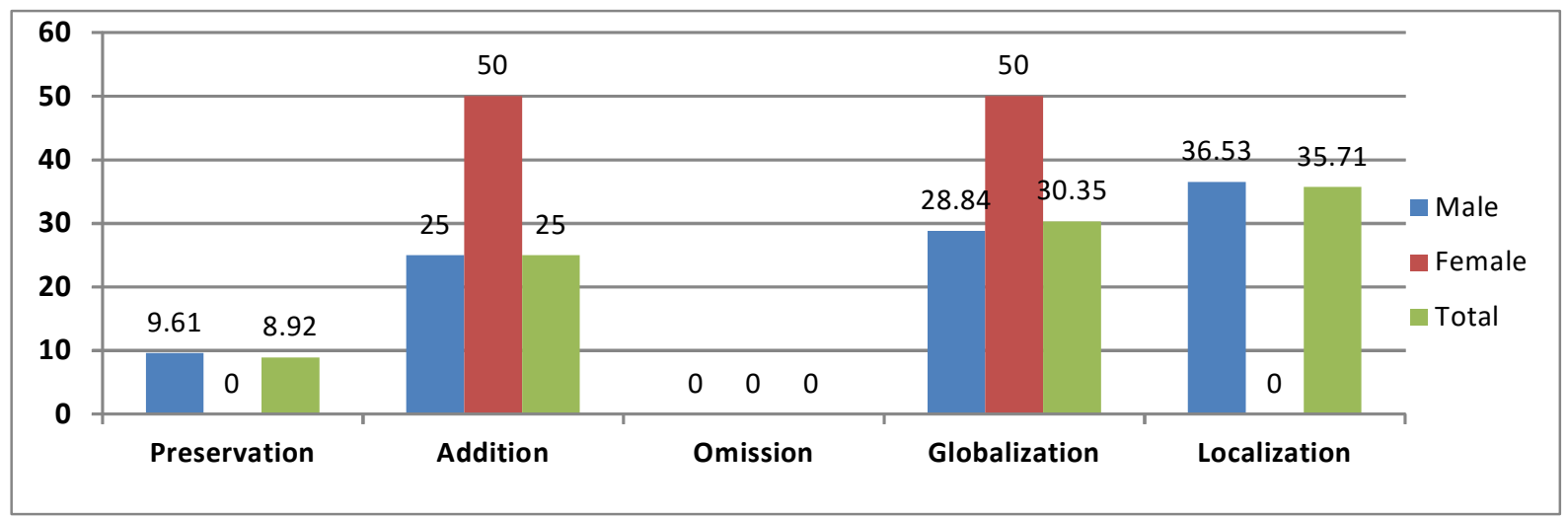

Figure 2. Percentage of Application of Strategies in Persian Corpus Concerning the Gender of the Translator

Table 11. Frequency and percentage of adopted strategies in English corpus concerning the gender of the translator

\begin{tabular}{lcccccccccc}
\hline Strategy & \multicolumn{2}{c}{ Preservation } & \multicolumn{2}{c}{ Addition } & \multicolumn{2}{c}{ Omission } & \multicolumn{2}{c}{ Globalization } & \multicolumn{2}{c}{ Localization } \\
\hline Measure & Fr. & $\%$ & Fr. & $\%$ & Fr. & $\%$ & Fr. & $\%$ & Fr. & $\%$ \\
\hline Male & 1 & 4.16 & 6 & 25 & 1 & 4.16 & 5 & 20.83 & 11 & 45.83 \\
\hline Female & 1 & 25 & 1 & 25 & 0 & 0 & 1 & 25 & 1 & 25 \\
\hline Total & 2 & 6.66 & 7 & 23.33 & 1 & 3.33 & 6 & 20 & 14 & 46.66 \\
& & & & & & & & & \multicolumn{2}{c}{$\begin{array}{c}\text { are } \\
\text { unknown }\end{array}$} \\
\hline
\end{tabular}

As the data of Table 11 shows the order of application of strategies by male translators in English corpus is: localization $(45.83 \%)$, addition $(25 \%)$, globalization $(20.83 \%)$, preservation $(4.16 \%)$ and omission $(4.16 \%)$. Female translators have used preservation, addition, globalization and localization with the same frequency $(25 \%)$. These data are depicted in Figure 3.

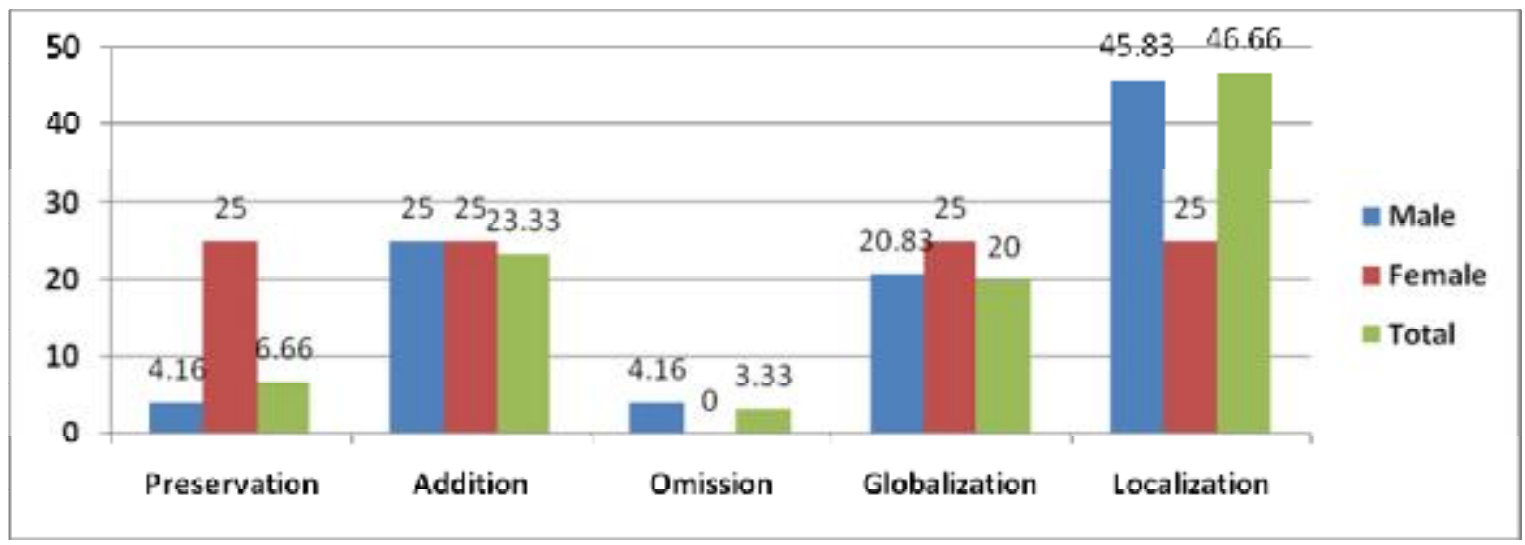

Figure 3. Percentage of Application of Strategies in English Corpus Concerning the Gender of the Translator

In Table 12 the data related to application of strategies in Persian and English corpus by female translators are provided.

Table 12. Percentage of application of strategies by female translators

\begin{tabular}{lccccc}
\hline Language & Preservation & Addition & Omission & Globalization & Localization \\
\hline Persian & 0 & 50 & 0 & 50 & 0 \\
\hline English & 25 & 25 & 0 & 25 & 25 \\
\hline
\end{tabular}

As is presented in Table 12, the female translators in Persian have more tendency to use globalization and addition $(50 \%)$ and in English the tendency of the translator is in using preservation, addition, globalization and localization $(25 \%)$. These data are depicted in Figure 4. 


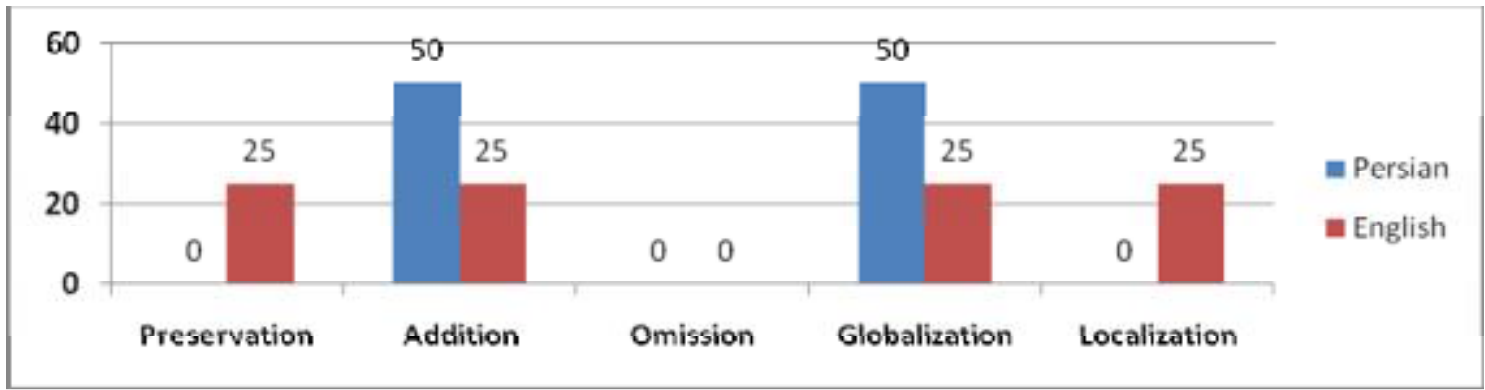

Figure 4. Strategies Adopted by Female Translators

In Table 13 the data related to application of strategies in Persian and English corpus by male translators are provided.

Table 13. Percentage of application of strategies by male translators

\begin{tabular}{lccccc}
\hline Language & Preservation & Addition & Omission & Globalization & Localization \\
\hline Persian & 9.61 & 25 & 0 & 28.84 & 36.53 \\
\hline English & 4.16 & 25 & 4.16 & 20.83 & 45.83 \\
\hline
\end{tabular}

In comparison with female adopted strategies, the male translators, as shown in Table 13 and depicted in Figure 5, in both Persian and English have more tendency to use the localization strategy, thus trying to make the term comprehensible for the people with different cultural background.

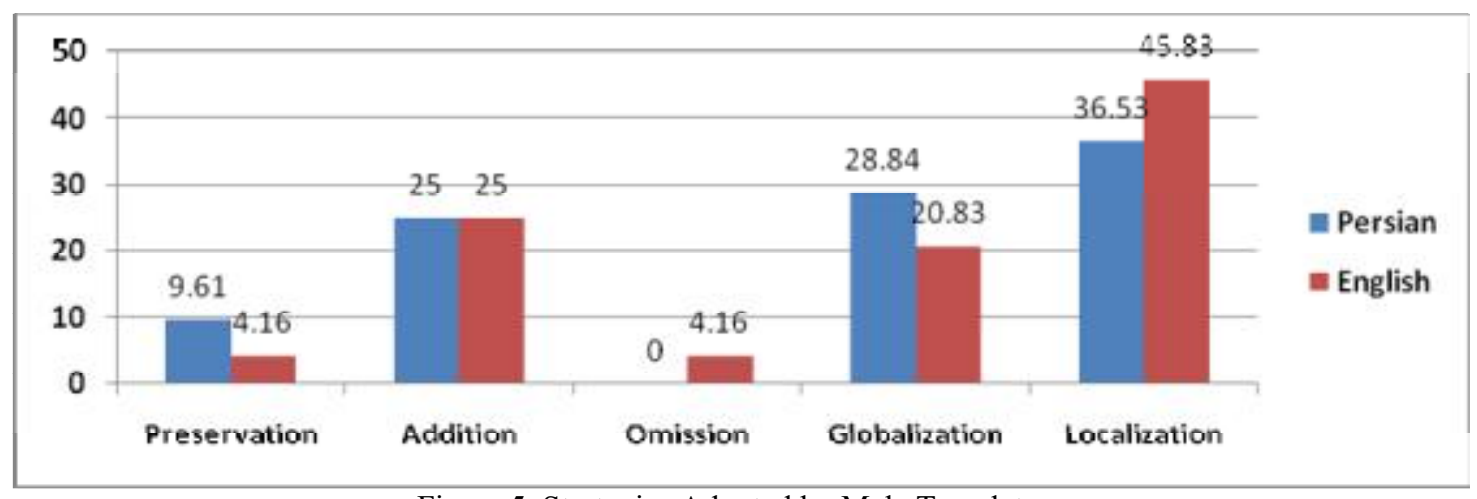

Figure 5. Strategies Adopted by Male Translators

Table 14 shows the division of application of one strategy by a gender to the total application of that strategy.

Table 14. Percentage and frequency of application of a strategy used by a specific gender to total usage of strategy

\begin{tabular}{lcccccccccc}
\hline Strategy & \multicolumn{2}{c}{ Preservation } & \multicolumn{2}{c}{ Addition } & \multicolumn{2}{c}{ Omission } & \multicolumn{2}{c}{ Globalization } & \multicolumn{2}{c}{ Localization } \\
\hline Measure & Fr. & $\%$ & Fr. & $\%$ & Fr. & $\%$ & Fr. & $\%$ & Fr. & $\%$ \\
\hline Male & 6 & 7.89 & 19 & 25 & 1 & 11.31 & 20 & 26.31 & 30 & 39.47 \\
\hline Female & 1 & 16.66 & 2 & 33.33 & 0 & 0 & 2 & 33.33 & 1 & 16.66 \\
\hline
\end{tabular}

As to Table 14, the male translators have more tendency to use localization $(39.47 \%)$, globalization $(26.31 \%)$ and addition (25\%); while female translators have shown more tendency to use globalization and addition (33.33\%), localization and preservation (16.66\%). These data are depicted in Figure 6.

Totally male translators are inclined to localization (39.47\%), while the female to globalization and addition (33.33\%). Thus, the male are trying to make the translation understandable for the TT receivers, actually moving the text to the reader, while the female are more conservative trying to maintain the ST cultural term, moving the reader to the text. 


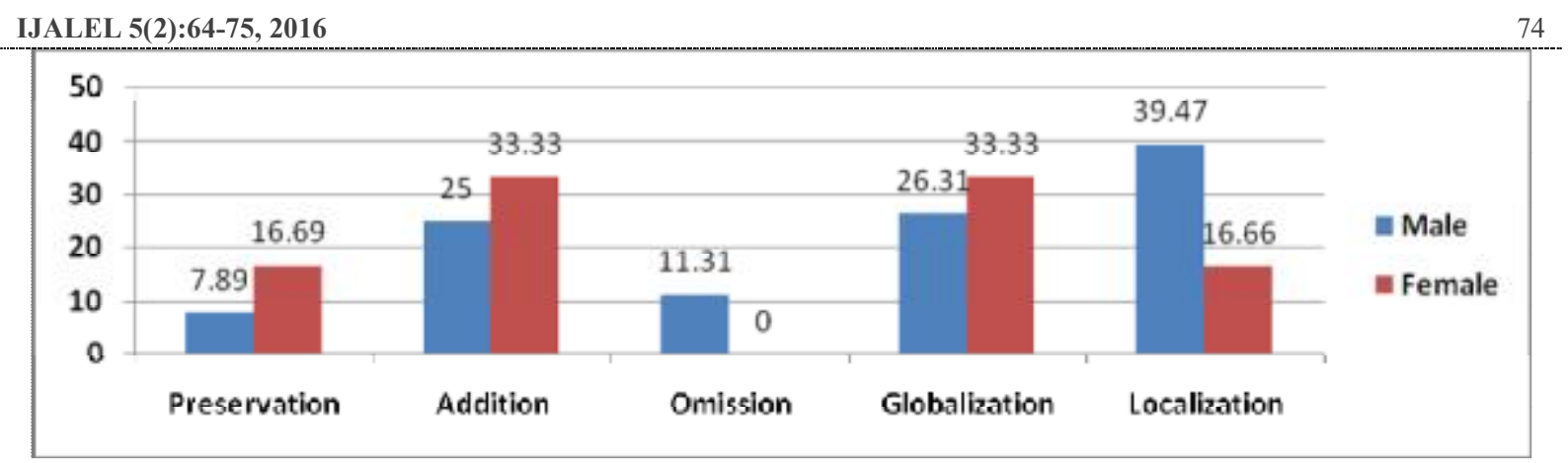

Figure 6. Percentage of Application of a Strategy Used by a Gender to Total Usage of it

\section{Conclusion}

The present study enjoying the theoretical framework presented by Davies for translating CSIs, was an attempt to compare Persian and English translation of Quranic-Arabic culture bound term "Jilbab", the name of clothes for women, with two concerns regarding the adopted strategies: a) linguistic (Persian and English) concern, translators' gender concern (male or female).

The analysis of data showed that the adopted strategies in order of application in a) total corpus (Persian and English corpus) were localization (39.53\%), globalization (26.74\%), addition (24.41\%), preservation (8.13\%) and omission $(1.16 \%)$; b) English corpus were: localization (46.66\%), addition (23.33\%), globalization (20\%), preservation $(6.66 \%)$, and omission (3.33\%); and c) Persian corpus were: localization (35.71\%), globalization (30.35\%), addition (\%25) and then preservation $(8.92 \%)$.

Female translators adopted strategies in order of application in a) total corpus were globalization and addition (33.33\%), preservation and localization $(16.66 \%)$, b) English corpus were preservation, addition, globalization and localization with the same percentage of usage $(25 \%)$, and c) Persian corpus only addition and globalization with the same percentage of usage $(50 \%)$.

Male translators adopted strategies in order of appearance in a) total corpus were localization (39.47\%), globalization (26.31\%), addition (25\%), preservation (7.89\%) and omission (11.31\%), b) English corpus were localization (45.83\%), addition (25\%), globalization (20.83\%), preservation (4.16\%) and omission (4.16\%), and c) Persian corpus localization (36.53\%), globalization (28.84\%), addition (25\%) and preservation $(9.61 \%)$.

The analysis of these data showed that in both Persian and English translations there was a tendency to use localization; thus it has been tried to make the equivalents of this word applicable for the people of different cultures living in different societies.

One of the by-findings of this research, concerning the different equivalents of term "Jilbab" during $4^{\text {th }}$ to $15^{\text {th }}$ centuary, was the fact that in both Persian and English there was one term which was used in all centuries: "chador" in Persian and "cloak" in English. Some other equivalents have been used repeatedly in $14^{\text {th }}$ and $15^{\text {th }}$ century such as: "مقع" "روسرى", "رويوش" in Persian and “outer garment” in English, attesting translators concern to previous periods chosen equivalents. And $15^{\text {th }}$ century was the period of appearance of various equivalents for this term in both Persian and English corpus, showing the expansion of cultural knowledge of the TT receivers, which has brought about translators freedom in choosing various equivalents.

\section{References}

Aixelá, J. F. (1996). Culture-specific items in translation. In R. Alvarez and M., C-A. Vidal (Eds.), Translation, power, subversion (pp. 52-78). Clevedon, UK: Multilingual Matters.

Baker, M. (1992). In other words: A course book on translation. London: Routledge.

Bakthiar, L. (2007). The sublime Quran. Kazi Publications.

Davies, E. E. (2003). A goblin or a dirty nose? The treatment of culture-specific references in translations of the Harry Potter books. The Translator, 9 (1), 65-100.

Dimitriu, R. (2004). Omission in translation. Perspectives: Studies in Translatology, 12 (3), 163-175.

Espindola, E. (2006). The use and abuse of subtitling as a practice of cultural representation: Cidade de Deus and Boyz ' $N$ the Hood. Santa Catarina: Universidade Federal de Santa Catarina.

Epindola, E., \& Vasconcellos, M. L. (2006). Two facets in the subtitling process: Foreignization and/or domestication procedures in unequal cultural encounters. Retrieved from http://www.periodicos.ufsc.br/index.php/fragmentos /article/.../7689.

Florin, S. (1993). Realia in translation. In P. Zlateva, (Ed.),Translation as social action: Russian and Bulgarian

Perspectives (pp. 122-128), London.

Gambier, Y. (2004). Doubts and directions in translation studies. The Netherlands: John Benjamins. 
Hagfors, I. (2003). The translation of culture-bound elements into Finnish in the post-war period. Meta: The Translators' Journal, 48 (1-2), 115-127.

Hervey, S. \& Higgins, I. (1992). Thinking translation: A course in translation method, French-English. London \& New York: Taylor \& Francis Routledge.

Ivir, V. (2002/2003). Translation of culture and culture of translation. SRAZ XLVII-XLVIII, 117-126.

Jami` al-Tafasir Noor (Version 2) [Computer software]. Retrieved from http://www.noorsoft.org.

Katan, D. (2009). Translation as intercultural communication. In J. Munday (Ed.), The Routledge companion to translation studies (74-92). Abingdon: Routledge.

Leppihalme, R. (2010). Realia. In Y. Gambier, \& L.V. Doorsler (Eds.), Handbook of Translation studies (volume2), (126-130). Amsterdm/Philadelphia: John Benjamins.

Mailhac, J. P. (1996). The formulation of translation strategies for cultural references. In C. Hoffman (Ed.), Language, culture and communication in contemporary Europe. Clevedon: Multilingual Matters.

Munday, J. (2006). Introducing translation studies, theories and application. London: Routledge.

Newmark, P. (1988). A textbook of translation. New York: Prentice-Hall International.

Nida, E. (1964). Towards a science of translating with special reference to principles and procedures involved in Bibl translating. Leiden: E. J. Brill.

Pavlović, N., \& Poslek, D. (2003). British and Croatian culture-specific concepts in translation. British Cultural Studies: Cross-Cultural Challenges, 157-168.

Robinson, D. (1997). Becoming a translator: An accelerated course. London: Routledge.

Saheeh International (Ed.). (1997). The Quran, Arabic text with corresponding English meanings. Abulqasim Publishing.

Sturge, K. (2009). Cultural translation. In M. Baker \& G. Saldanha (Eds.), Routledge encyclopedia of translation studies, (67-70). New York: Routledge.

Thriveni, C. (2001). Cultural elements in translation: the Indian perspective. Retrieved from http://www.translationdirectory.com /article24.htm.

Venutie, L. (Ed.). (1992). Rethinking Translation: Discourse, Subjectivity, ideology. London and New York: Routledge. 